\title{
Biosynthesis of $\alpha-\mathrm{Fe}_{2} \mathrm{O}_{3}-\mathrm{CdO}$ Nanocomposites for Electrochemical Detection of Chloridazon Herbicide
}

\author{
Puthalapattu Aruna ${ }^{1}$, Puthalapattu Reddy Prasad ${ }^{2, *}$, , Punyasamudram Sandhya ${ }^{3}$ (D) , N.V.S.S. Seshagiri \\ Rao $^{4}$ (D), Neelam Yugandhar Sreedhar ${ }^{1}$ \\ 1 Electroanalytical Lab, Department of Chemistry, S.V.University, Tirupati-517502, A.P, India; \\ arunaputhalapattu@gmail.com(P.A.); \\ 2 Department of Chemistry, Institute of Aeronautical Engineering (IARE), Dundigal-500043, Hyderabad, India; \\ prprasad@iare.ac.in (P.R.P.); \\ 3 Department of Chemistry, Sri Padmavati Mahila Visvavidyalayam, Tirupati-517502, A.P., India; sanrchem@gmail.com \\ (P.S.); \\ 4 Department of Physics, Institute of Aeronautical Engineering (IARE), Dundigal-500043, Hyderabad, India; \\ seshu.nvss2004@gmail.com (N.V.S.S.S.R.); \\ * Correspondence: prprasadchem@gmail.com (P.R.P.);
}

Scopus Author ID 16317364300

Received: 28.08.2021; Revised: 5.10.2021; Accepted: 8.10.2021; Published: 22.10.2021

\begin{abstract}
Biosynthesised $\alpha-\mathrm{Fe}_{2} \mathrm{O}_{3}-\mathrm{CdO}$ electrochemical nanosensor attained from Coriandrum sativum leaves extract and fabricated on the screen-printed electrode to detect chloridazon (CLZ) herbicide in agricultural food samples. Scanning electron microscopy, energy dispersive $\mathrm{x}$-ray analysis, $\mathrm{X}$-ray diffraction spectroscopy, cyclic voltammetry, and differential pulse voltammetry were used to investigate the $\alpha-\mathrm{Fe}_{2} \mathrm{O}_{3}-\mathrm{CdO}$ electrochemical nanosensor. The optimization factors of the effect of $\mathrm{pH}$, accumulation time, accumulation potential, and foreign substances were elevated. The $\alpha-\mathrm{Fe}_{2} \mathrm{O}_{3^{-}}$ $\mathrm{CdO} / \mathrm{SPE}$ electrochemical nanosensor shows the significant voltammetric response for the CLZ detection. Foreign substances did not considerably influence pesticide detection. Dynamic linear CLZ plot for a standard solution of CLZ was obtained in the concentration range of 0.1 to $36.00 \mu \mathrm{g} \cdot \mathrm{mL}^{-1}$ $(\mathrm{R}=0.995)$ with a limit of detection $0.059 \mu \mathrm{g} \cdot \mathrm{mL}^{-1}$ and a quantification limit of $0.179 \mu \mathrm{g} \cdot \mathrm{mL}^{-1}$. The proposed electrochemical nanosensor was used to detect CLZ in agricultural food samples and agreeable recovery results.
\end{abstract}

Keywords: chloridazon; electrode; nanosensor; herbicide; agricultural food.

(C) 2021 by the authors. This article is an open-access article distributed under the terms and conditions of the Creative Commons Attribution (CC BY) license (https://creativecommons.org/licenses/by/4.0/).

\section{Introduction}

Chloridazon (CLZ) (5-amino-4-bromo-2-phenylpyridazin-3(2H)-one) acts as a systemic leaf and soil herbicide by inhibiting the photosynthesis that belongs to the group of pyradazinone [1]. It was used for pre-plant, pre-emergence, and early post-emergence use to control annual broad-leaved weeds on sugar beets and red table beets [2]. Existing data indicate that CLZ is portable in various soil types, and in this way, it has the potential to enter surface and groundwater [2,3]. Uncertainly, it perseveres for a long time because its degradation is slow and harmful to the human being [4,5]; therefore, it is concerned with monitoring pesticides [6-8]. Many investigators have reported monitoring pesticide residues in food, water, and soil samples [9-16].

Voltammetric methods have been widely working on pesticide detection at bare electrodes [17]. Recently, the use of voltammetry on carbon paste electrode (CPE) [18], silver- 
amalgam film electrode ( $\mathrm{Hg}(\mathrm{Ag}) \mathrm{FE})$ [19], bismuth film electrode (BiFE) [20], and screen printed electrode (SPE) [21] was described. Bare electrodes have limitations that are overcome by using electrodes whose surfaces are modified with specific conductivity species. The modified screen-printing technology is well established for the production of thick-film electrochemical transducers [22]. This technology allows the mass production of highly reproducible, disposable, single-use screen-printed electrodes (SPEs) at a reduced cost [22,23]. To increase sensitivity and selectivity in the pesticide determination, different modification procedures of usual electrodes were applied. Though metal oxide nanostructures are extensively applied in significant disciplines such as optoelectronics, catalysis, dye-sensitizer solar cell, and sensor applications [24-26] because they provide a high surface area to volume ratio, hydrothermal stability, and various oxidation states, they possess unique optical, magnetic and electronic properties [27].

In the present investigation, the nanostructured $\alpha-\mathrm{Fe}_{2} \mathrm{O}_{3}-\mathrm{CdO}$ electrochemical nanosensor can be effortlessly prepared from Coriandrum sativum leaves extract. An electrochemically investigated the CLZ pesticide in agricultural food samples using biosynthesized $\alpha-\mathrm{Fe}_{2} \mathrm{O}_{3}-\mathrm{CdO} / \mathrm{SPE}$ electrochemical nanosensor. The $\alpha-\mathrm{Fe}_{2} \mathrm{O}_{3}-\mathrm{CdO} / \mathrm{SPE}$ electrochemical nanosensor has shown satisfactory recovery results for the quantified residues of CLZ pesticide in agricultural food samples by DPV. Under the optimized voltammetric operational conditions, the established $\alpha-\mathrm{Fe}_{2} \mathrm{O}_{3}-\mathrm{CdO} / \mathrm{SPE}$ electrochemical nanosensor exhibited a specific and excellent electrocatalytic performance with a good sensitivity, selectivity, and wide dynamic concentration range towards the quantification of CLZ.

\section{Materials and Methods}

$\mathrm{CdCl}_{2}, \mathrm{FeCl}_{3}, \mathrm{FeCl}_{2}$, Nafion, $\mathrm{H}_{3} \mathrm{BO}_{3}, \mathrm{H}_{3} \mathrm{PO}_{4}$, glacial acetic acid, $\mathrm{NaOH}$, and glucose were purchased from Merck Chemicals. Dopamine, uric acid, hydroquinone, ascorbic acid, and urea were purchased from Sigma-Aldrich. Beyer's chemicals provided the chloridazon. A stock solution of CLZ $\left(1000 \mu \mathrm{g} \cdot \mathrm{mL}^{-1}\right)$ was prepared by dissolving CLZ in a suitable amount of methanol. Briton-Robison (BR) buffer solution ranging from $\mathrm{pH} 2.0$ to 12.0 was prepared using extra pure acetic acid, phosphoric acid, and boric acid. For adjusting the $\mathrm{pH}$ of the solution, perchloric acid and sodium hydroxide were used. All aqueous solutions were made with deionized water from the Millipore direct-Q water system. All of the substances were reagentgrade analytical compounds.

\subsection{Apparatus.}

Electrochemical quantifications were carried out in Auto-Lab consisting of the modified screen-printed electrode as a working electrode. Before an electrochemical investigation, the experimental solutions were degassed by purified nitrogen gas in the voltammetric cell for $2 \mathrm{~min}$. Scanning electron microscopy (SEM) images were acquired using an FEI-quanta 200 scanning electron microscope with a $10 \mathrm{kV}$ acceleration voltage. X-ray powder diffraction (XRD) spectroscopy was used to determine the crystal structure of the resultant products using an X'Pert-Pro MPD (Holland) D/max- $\gamma$ AX-ray diffractometer with $\mathrm{Cu} \mathrm{K \alpha}$ radiation $(\lambda=0.154178)$. All the experiments were performed at $25 \pm 1{ }^{\circ} \mathrm{C}$, and $\mathrm{pH}$ measurements were carried out with Hanna instruments (Italy) $\mathrm{pH}$ meter. 


\subsection{Preparation of Coriandrum sativum leaves extract.}

Fresh leaves of Coriandrum sativum (kothimeera) were collected from a local market in Tirupati, Andhra Pradesh, India. The collected leaves were rinsed carefully with distilled water and left to dry for a few hours. Then, the dried leaves were powdered in a mortar, and 20 $\mathrm{g}$ of powdered leaves were mixed with $200 \mathrm{ml}$ deionized water and heated at $80{ }^{\circ} \mathrm{C}$ using a heater-stirrer for $30 \mathrm{~min}$. The mixture was then filtered and centrifuged to eliminate plant residues and contaminants before being preserved for further study.

\subsection{Biosynthesis of $\alpha-\mathrm{Fe}_{2} \mathrm{O}_{3}-\mathrm{CdO}$.}

A typical green process was applied to make the $\alpha-\mathrm{Fe}_{2} \mathrm{O}_{3}-\mathrm{CdO}$ electrochemical nanosensor. For this, $50 \mathrm{~mL}$ aliquots of $0.03 \mathrm{~mol} \mathrm{~L}^{-1} \mathrm{FeCl}_{3}, 0.01 \mathrm{~mol} \mathrm{~L}^{-1} \mathrm{CdCl}_{2}$ solutions were prepared and transferred into a $250 \mathrm{~mL}$ beaker under constant stirring. Meanwhile, $100 \mathrm{~mL}$ of coriander leaves extract was gradually added to the $250 \mathrm{~mL}$ beaker and stirred at $80{ }^{\circ} \mathrm{C}$ for 6 hours with a magnet stirrer. Then the $\mathrm{pH}$ is adjusted to reach a $\mathrm{pH}$ value of 10.0 by adding an amount of $0.02 \mathrm{~mol} \mathrm{~L}^{-1} \mathrm{NaOH}$ drop by drop under stirred conditions. The mixture was stirred until a solid product with a light brownish-black color was obtained. Later, the obtained solid product was filtered and washed with double deionized water and ethanol in sequence and dried in a vacuum at $100{ }^{\circ} \mathrm{C}$ at $12 \mathrm{~h}$. The brown-black $\alpha-\mathrm{Fe}_{2} \mathrm{O}_{3}-\mathrm{CdO}$ was obtained by calcining the produced heterogeneous nanostructure at $350{ }^{\circ} \mathrm{C}$ for $3 \mathrm{~h}$ at a heating rate of $1{ }^{\circ} \mathrm{C}$ min. $\alpha-\mathrm{Fe}_{2} \mathrm{O}_{3}$ and $\mathrm{CdO}$ were prepared using the procedure described for comparison purposes.

For an electrochemical measurement, the $20 \mathrm{mg}$ of $\alpha-\mathrm{Fe}_{2} \mathrm{O}_{3}-\mathrm{CdO}$ nanocomposite was dispersed in $0.5 \mathrm{~mL}$ nafion (2\%) and made the paste for drop-casting. The SPE surface was modified with a slurry of $\alpha-\mathrm{Fe}_{2} \mathrm{O}_{3}-\mathrm{CdO}$ paste and dried at room temperature for $60 \mathrm{~min}$ for using it as a working electrode. Similarly, $\alpha-\mathrm{Fe}_{2} \mathrm{O}_{3} / \mathrm{SPE}$ and $\mathrm{CdO} / \mathrm{SPE}$ working electrodes were prepared as a working electrode for assessment study.

\subsection{Sample collection and preparation.}

Meanwhile, the agricultural food samples were obtained from a local vegetable market in Rythu Bazar, Tirupati, Chittoor District, A.P. The food samples of spinach, lettuce, cauliflower, cucumber, and cabbage were washed with distilled water and stored in airtight plastic at $-4{ }^{\circ} \mathrm{C}$ until evaluated. The chopped vegetable samples were weighed at $40 \mathrm{~g}$ and spiked with an appropriate amount of pesticide before resting for 30 minutes at room temperature. After that, $2 \mathrm{~mL}$ of acetonitrile was added, and the solution was homogenized by shaking for $20 \mathrm{~min}$ to ensure complete solvent evaporation. Then, the samples were centrifuged at $3600 \mathrm{rpm}$ for $20 \mathrm{~min}$, and the liquid supernatant was analyzed by voltammetry.

In the voltammetric cell, $10.0 \mathrm{~mL}$ of $6.0 \mu \mathrm{g} \cdot \mathrm{mL}^{-1} \mathrm{CLZ}$ standard solution is transferred and added the required amount of BR buffer ( $\mathrm{pH}$ 5.0). After attaining the voltammogram, required additions of standard solutions are added. After each addition, the voltammogram was recorded under similar experimental conditions. The accumulation time: $40 \mathrm{~s}$; accumulation potential: $-1.08 \mathrm{~V}$; scan rate: $40 \mathrm{mVs}^{-1}$ and pulse amplitude: $30 \mathrm{mV}$ are found to be the voltammetry optimum parameters for the detection of CLZ. 


\section{Results and Discussion}

The $\alpha-\mathrm{Fe}_{2} \mathrm{O}_{3}-\mathrm{CdO}$ electrochemical nanosensor was successfully attained via a modest and facile biosynthesis method. As synthesized $\alpha-\mathrm{Fe}_{2} \mathrm{O}_{3}-\mathrm{CdO}$ electrochemical nanosensor morphological structure was investigated by scanning electron microscope (SEM), X-ray diffraction (XRD), and energy-dispersive x-ray analysis (EDX). The morphology of $\alpha-\mathrm{Fe}_{2} \mathrm{O}_{3}$ $\mathrm{CdO}$ nanocomposite was characterized by SEM at two different magnifications (Figure. 1). The typical SEM images of synthesized $\alpha-\mathrm{Fe}_{2} \mathrm{O}_{3}-\mathrm{CdO}$ nanocomposites appeared carrying the formed $\alpha-\mathrm{Fe}_{2} \mathrm{O}_{3}-\mathrm{CdO}$ nanocomposites, which are nearly spherical-like shapes with random distribution (see Figures. 1A \& 1B). The SEM images reveal the rough and uneven surface of the nanocomposites, which exhibited the diameter of the particles around $\sim 36 \mathrm{~nm}$ with a length of about $1 \mu \mathrm{m}$ and $200 \mathrm{~nm}$ magnifications. The EDX patterns and corresponding atomic compositions for $\alpha-\mathrm{Fe}_{2} \mathrm{O}_{3}-\mathrm{CdO}$ have been presented in Figure 1C. The atomic percentages reveal that the $\alpha-\mathrm{Fe}_{2} \mathrm{O}_{3}-\mathrm{CdO}$ nanocomposites were successfully synthesized through the green procedure. Further lattice morphology and phase composition of $\alpha-\mathrm{Fe}_{2} \mathrm{O}_{3}-\mathrm{CdO}$ are confirmed by powder XRD (Figure. 2). All the intense peaks of the face centered cubic $\mathrm{CdO}$ are observed in the recorded XRD; the peaks at 2 theta values of $29.4^{\circ}, 33.6^{\circ}, 43.5^{\circ}, 49.5^{\circ}, 53.2^{\circ}, 66.2^{\circ}$, and $69.3^{\circ}$ matches with $210,111,202,024,116,311$, and 222 peaks given by JCPDS card no. 652908 [28]. The XRD confirms the presence of $\mathrm{CdO}$ in a cubic lattice. The 202 and 024 peaks of $\alpha-\mathrm{Fe}_{2} \mathrm{O}_{3}$ at 2 theta values of 43.5 and 49.5 indicate the presence of $\alpha-\mathrm{Fe}_{2} \mathrm{O}_{3}$ in rhombohedral crystal lattice given by JCPDS card no.80-2377 [28]. Because of the low atomic weight, the $\alpha-$ $\mathrm{Fe}_{2} \mathrm{O}_{3}-\mathrm{CdO}$ peaks have modest intensities. The characterization characteristic diffraction peaks of the $\alpha-\mathrm{Fe}_{2} \mathrm{O}_{3}-\mathrm{CdO}$ electrochemical nanosensor are completely comprised by the XRD patterns of $\alpha-\mathrm{Fe}_{2} \mathrm{O}_{3}-\mathrm{CdO}$ nanomaterials, showing that the hybrid nanocomposites are successfully synthesized using $\alpha-\mathrm{Fe}_{2} \mathrm{O}_{3}$ and $\mathrm{CdO}$ precursors [29]. In the spectrum of the $\alpha-$ $\mathrm{Fe}_{2} \mathrm{O}_{3}-\mathrm{CdO}$ sensor, a broad peak of graphitic-like carbon was also seen at $23^{\circ}$, as reported [30].

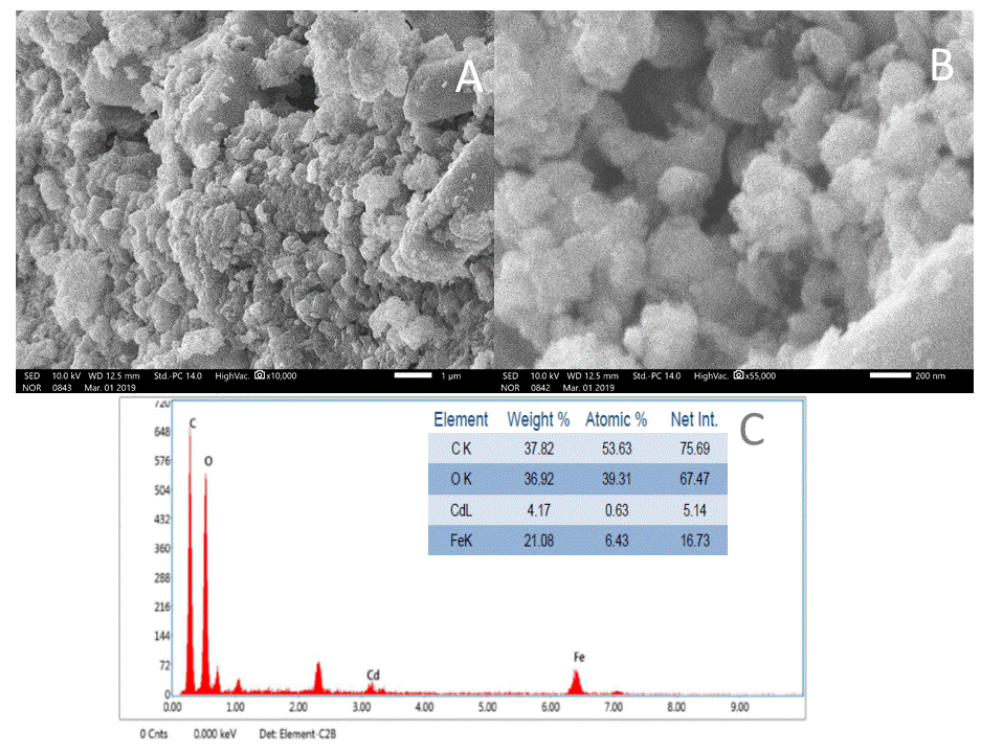

Figure 1. (A, B) SEM images of $\alpha-\mathrm{Fe}_{2} \mathrm{O}_{3}-\mathrm{CdO}$ nanocomposite at two magnifications (C) EDX.

Using cyclic voltammetry in $0.1 \mathrm{~mol} \mathrm{~L}^{-1} \mathrm{pH}$ 5.0 BR buffer solutions in the presence of $6.0 \mu \mathrm{g} \cdot \mathrm{mL}^{-1}$ of CLZ at a scan rate of $40 \mathrm{mVs}^{-1}$, the electrochemical behavior of CLZ at bare SPE, $\alpha-\mathrm{Fe}_{2} \mathrm{O}_{3} / \mathrm{SPE}, \mathrm{CdO} / \mathrm{SPE}$, and $\alpha-\mathrm{Fe}_{2} \mathrm{O}_{3}-\mathrm{CdO} / \mathrm{SPE}$ is investigated (Figure. 3). As seen in the cyclic voltammogram, utilizing bare SPE produced no reduced peak current $\left(\mathrm{I}_{\mathrm{pc}}\right)$ (Figure. 
3 curve a). On the CdO/SPE (Figure. 3 curve b), the less reduction peak currents have formed due to reduced electron transfer between the electrodes, suggesting the $\mathrm{CdO}$ substances' low sensitivity on the SPE. When the SPE was modified with $\alpha-\mathrm{Fe}_{2} \mathrm{O}_{3}$, it was found that the reduction peak current has been increased at $-1.0 \mathrm{~V}$ (Figure. 3 curve c) because of the small size and high surface area of the nanoparticle enhanced the electron mobility. On the other hand, on $\alpha-\mathrm{Fe}_{2} \mathrm{O}_{3}-\mathrm{CdO} / \mathrm{SPE}$ (Figure. 3 curve d) at $-1.08 \mathrm{~V}$, a well-defined redox peak current of CLZ is significantly enhanced, which is more prominent than those obtained at the bare SPE, $\alpha-\mathrm{Fe}_{2} \mathrm{O}_{3} / \mathrm{SPE}$, and $\mathrm{CdO} / \mathrm{SPE}$. This indicates that $\alpha-\mathrm{Fe}_{2} \mathrm{O}_{3}$ and $\mathrm{CdO}$ have a considerable influence on the SPE's electron transfer kinetics. The enhanced electron transport due to the biosynthesized entangled $\alpha-\mathrm{Fe}_{2} \mathrm{O}_{3}-\mathrm{CdO}$ structure and the good affinity of CLZ with $\alpha-\mathrm{Fe}_{2} \mathrm{O}_{3}-$ $\mathrm{CdO}$ can be attributed to the improved performance of the $\alpha-\mathrm{Fe}_{2} \mathrm{O}_{3}-\mathrm{CdO} / \mathrm{SPE}$ combination nanocomposite. The rate-determining phase of CLZ's electrochemical process is seen in Figure $4[31]$.

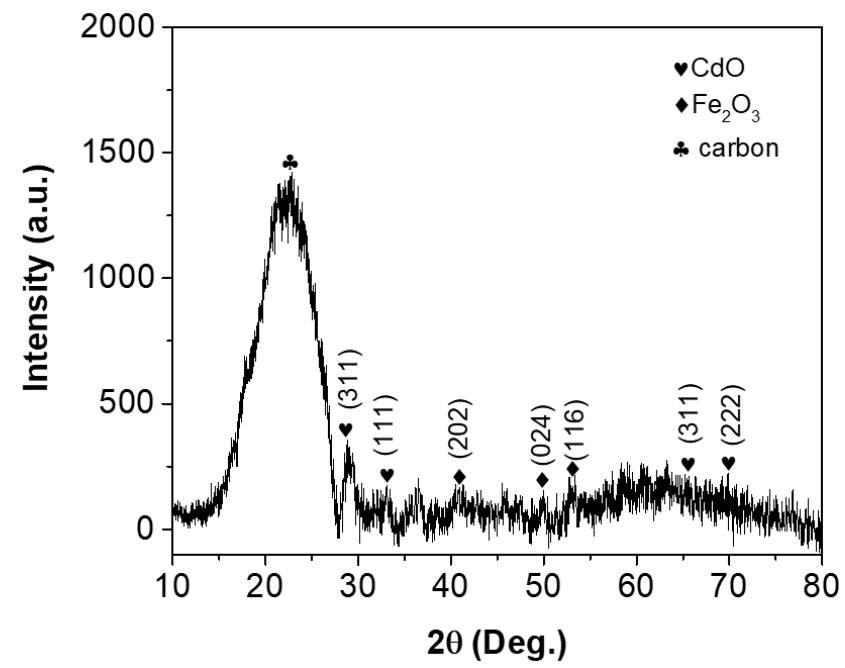

Figure 2. XRD spectrum of $\alpha-\mathrm{Fe}_{2} \mathrm{O}_{3}-\mathrm{CdO}$ electrochemical nanosensor.

The differential pulse voltammetric response of $6.0 \mu \mathrm{g} \cdot \mathrm{mL}^{-1} \mathrm{CLZ}$ (pH 5.0 BR buffer) at bare SPE, CdO/SPE, $\alpha-\mathrm{Fe}_{2} \mathrm{O}_{3} / \mathrm{SPE}$, and $\alpha-\mathrm{Fe}_{2} \mathrm{O}_{3}-\mathrm{CdO} / \mathrm{SPE}$ is examined as shown in Figure 5. After 3 min of open-circuit accumulation in a pH 5.0 BR buffer, a slight reduction peak on $-1.0 \mathrm{~V}$ at $\mathrm{CdO} / \mathrm{SPE}$ (Figure. 5 curve b) developed, which is better than bare SPE (Figure. 5 curve a). Under differential voltammetric conditions, feeble reduction peak current appeared at $\alpha-\mathrm{Fe}_{2} \mathrm{O}_{3} / \mathrm{SPE}$ (Figure. 5 curve c); though, it has been significantly increased at the $\alpha-\mathrm{Fe}_{2} \mathrm{O}_{3}$ CdO modified SPE (Figure 5 curve d). The peak current increase may have been caused by the fact that the biosynthesized $\alpha-\mathrm{Fe}_{2} \mathrm{O}_{3}-\mathrm{CdO}$ nanocomposite has a high surface area and forms a perfect film on the SPE surface. Compared with $\mathrm{CdO} / \mathrm{SPE}$ and $\alpha-\mathrm{Fe}_{2} \mathrm{O}_{3} / \mathrm{SPE}$ the reduction peak current for the $\alpha-\mathrm{Fe}_{2} \mathrm{O}_{3}-\mathrm{CdO}$ coated SPE increases significantly under comparable conditions, and the reduction peak potential does not change much. The remarkable peak current enhancement is undoubtedly attributed to the extraordinary properties of biosynthesized $\alpha$ $\mathrm{Fe}_{2} \mathrm{O}_{3}$ and $\mathrm{CdO}$, such as good electronic properties, high aspect ratio, and strong absorptive ability. This result further confirms that the $\alpha-\mathrm{Fe}_{2} \mathrm{O}_{3}-\mathrm{CdO}$ nanocomposites have a superior activity for catalytic of CLZ reduction. Therefore, carbon mediated nanocomposites screenprinted electrode improves the electrocatalytic activity. Thus, the sensitivity of the $\alpha-\mathrm{Fe}_{2} \mathrm{O}_{3}-$ $\mathrm{CdO}$ electrochemical nanosensor can be improved greatly to determine CLZ in agricultural food samples. 
The influence of supporting electrolytes and $\mathrm{pH}$ on DPV for $6.0 \mu \mathrm{g} \cdot \mathrm{mL}^{-1} \mathrm{CLZ}$ with $\alpha$ $\mathrm{Fe}_{2} \mathrm{O}_{3}-\mathrm{CdO} / \mathrm{SPE}$ was evaluated in various supporting electrolytes, including $0.1 \mathrm{M}$ BrittonRobinson buffer, $0.1 \mathrm{M}$ sodium acetate -acetic acid buffer, $0.1 \mathrm{M}$ phosphate buffer, carbonate buffer, and borate buffer solution. The maximum peak current was obtained using $0.1 \mathrm{M}$ Britton-Robison buffer/acetonitrile (10:1, V/V) as the supporting electrolyte among the various buffers examined in the $\mathrm{pH}$ range of 2.0-12.0. As shown, the current density increased with $\mathrm{pH}$ values by increasing until a maximum value of $\mathrm{pH} 5.0$ had arrived, and then the current density decreased when the $\mathrm{pH}$ value still increased from 5.5. This kind of phenomenon is because the CLZ pesticide and $\mathrm{H}+$ are both required in the irreversible reduction, but the electrode structure can be destroyed if the acidity is too low. Thus, the best voltammetric signal in terms of sensitivity (peak height) was obtained at $\mathrm{pH} 5.0$ (Britton-Robison buffer) with acetonitrile supporting electrolyte media (10:1 V/V) as shown in Figure 6.

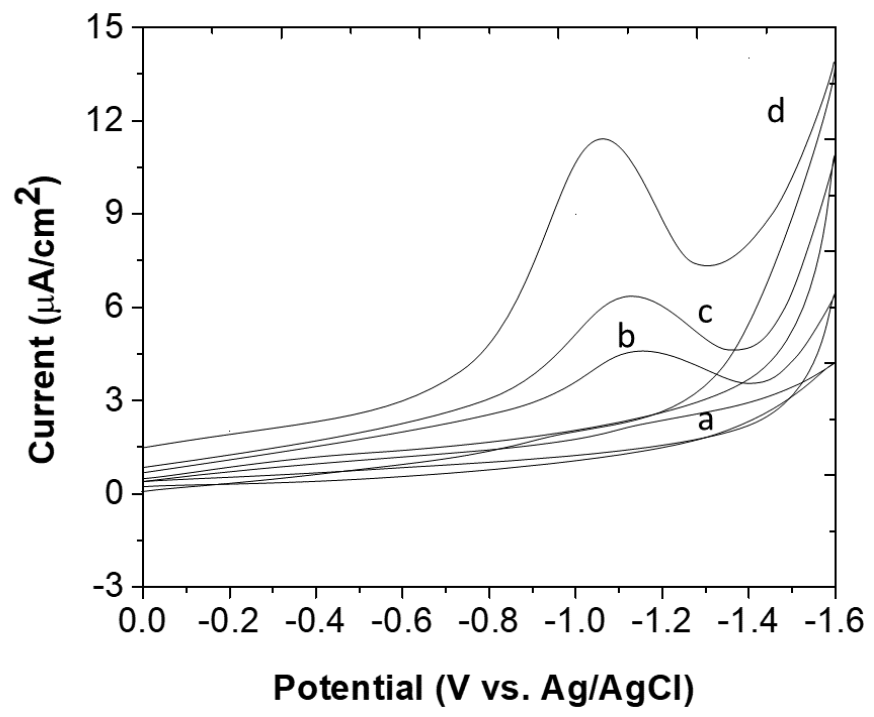

Figure 3. Cyclic voltammogram of CLZ at bare SPE (a), CdO/SPE (b), $\alpha-\mathrm{Fe}_{2} \mathrm{O}_{3} / \mathrm{SPE}$ (c), $\alpha-\mathrm{Fe}_{2} \mathrm{O}_{3}-\mathrm{CdO} / \mathrm{SPE}$ (d); pH: 5.0 (BR buffer/acetonitrile); accumulation potential: $-1.08 \mathrm{~V}$; accumulation time: $40 \mathrm{~s}$; scan rate: $40 \mathrm{mVs}^{-1}$, pulse amplitude: $30 \mathrm{mV}$; concentration: $6.0 \mu \mathrm{g} \cdot \mathrm{mL}^{-1}$.<smiles>Nc1cnn(-c2ccccc2)c(=O)c1Cl</smiles>

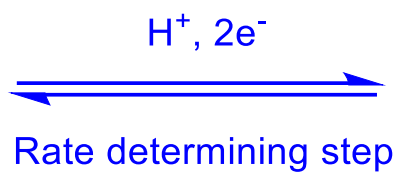<smiles>NC1=C(Cl)C(O)N(c2ccccc2)N=C1</smiles>

Figure 4. Electrochemical reduction mechanism of CLZ.

To improve the method's sensitivity and limit of detection, the effect of accumulation potential and accumulation time on the DPV signal has been studied. Figure 7, shows the influence of the accumulation potential on the peak height that has been studied from -0.2 to $1.6 \mathrm{~V}$, and strong adsorption at $-1.0 \mathrm{~V}$ was observed, so this potential was used as the accumulation potential for all the measurements. The consequence of accumulation time $t_{\text {acc }}$ (sec.) on the differential pulse peak current of the first peak CLZ in BR buffer of pH 5.0 is investigated. As shown in Figure 8, an accumulation time of $40 \mathrm{~s}$, at $-1.0 \mathrm{~V}$ generated a significant peak current. The influence of the scan rate $\left(E_{j}\right)$ on the electrochemical reduction of $6.0 \mu \mathrm{g} \cdot \mathrm{mL}^{-1} \mathrm{CLZ}$ using DPV was studied in the range of $10-100 \mathrm{mVs}^{-1}$ on the $\alpha-\mathrm{Fe}_{2} \mathrm{O}_{3}-$ $\mathrm{CdO} / \mathrm{SPE}$. When a scan rate of $40 \mathrm{mVs}^{-1}$ was applied, plotting $\log \mathrm{i}_{\mathrm{p}}$ versus $\log \mathrm{v}$ gave a straight 
line with a slope of $0.91(\mathrm{r}=0.995)$ close to 1 , which is the expected slope for an ideal reaction surface species. The effect of pulse parameters on CLZ voltammetric response has been calculated. Another important parameter involved in DPV is the pulse amplitude $\left(E_{a}\right)$. The effect of DPV pulse amplitude on the reduction peak current of $6.0 \mu \mathrm{g} \cdot \mathrm{mL}^{-1}$ CLZ in $0.1 \mathrm{M}$ of BR buffer/acetonitrile was studied from $20-100 \mathrm{mV}$ and modulation time of $25-75 \mathrm{~ms}$ respectively. The highest reduction currents have been obtained for the pulse amplitude of 30 $\mathrm{mV}$ and modulation time of $20 \mathrm{~ms}$ that have been used for further measurements.

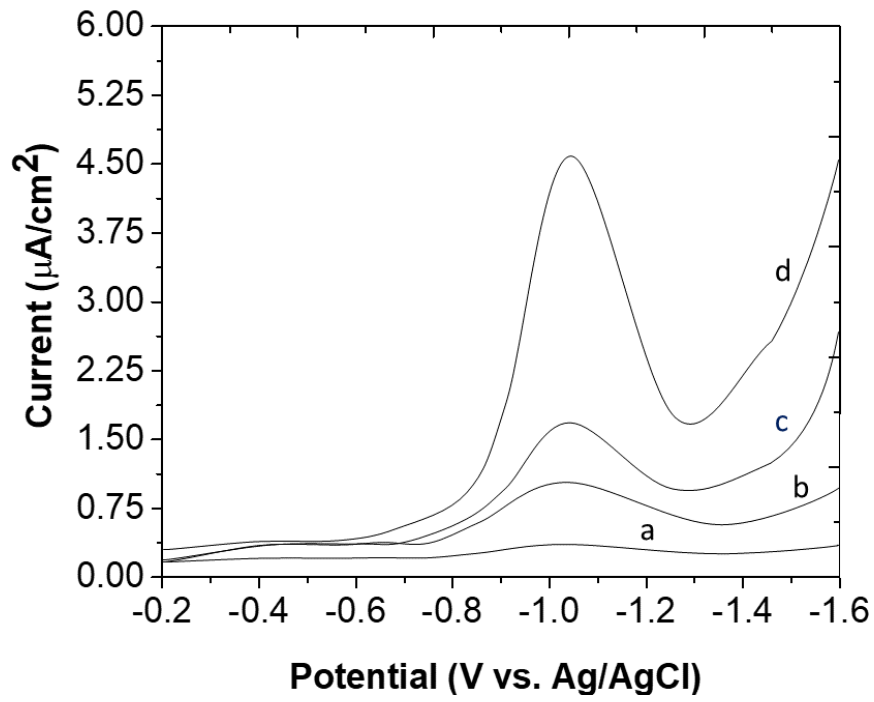

Figure 5. Differential pulse voltammogram of CLZ at bare SPE (a) CdO/SPE (b), $\alpha-\mathrm{Fe}_{2} \mathrm{O}_{3} / \mathrm{SPE}$ (c), $\alpha-\mathrm{Fe}_{2} \mathrm{O}_{3}-$ CdO/SPE (d); pH: 5.0 (BR buffer/acetonitrile); accumulation potential: $-1.08 \mathrm{~V}$; accumulation time: $40 \mathrm{~s}$; scan rate: $40 \mathrm{mVs}^{-1}$, pulse amplitude: $30 \mathrm{mV}$; concentration: $6.0 \mu \mathrm{g} \cdot \mathrm{mL}^{-1}$.

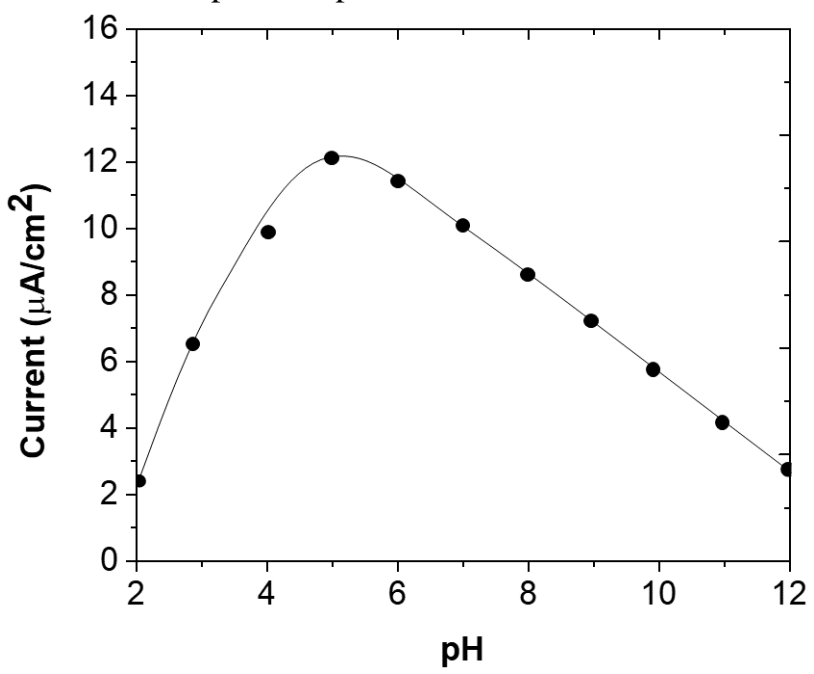

Figure. 6. Effect of $\mathrm{pH}$ on the differential pulse voltammetry of CLZ at $\alpha-\mathrm{Fe}_{2} \mathrm{O}_{3}-\mathrm{CdO} / \mathrm{SPE}$; accumulation time: $40 \mathrm{~s}$; accumulation potential: $-1.08 \mathrm{~V}$; accumulation time: $40 \mathrm{~s}$; scan rate: $40 \mathrm{mVs}^{-1}$, pulse amplitude: $30 \mathrm{mV}$; concentration: $6.0 \mu \mathrm{g} \cdot \mathrm{mL}^{-1}$.

The effects of some of the organic and inorganic foreign species on the voltammetric detection of CLZ were investigated by using $\alpha-\mathrm{Fe}_{2} \mathrm{O}_{3}-\mathrm{CdO} / \mathrm{SPE}$ at $\mathrm{pH} 5.0$ (BR buffer) with acetonitrile supporting electrolyte $(10: 1 \mathrm{~V} / \mathrm{V})$. The electrocatalytic reduction response of the electrochemical sensor of $\alpha-\mathrm{Fe}_{2} \mathrm{O}_{3}-\mathrm{CdO}$ towards $\left(1.0,6.0\right.$ and $\left.15 \mu \mathrm{g} \cdot \mathrm{mL}^{-1}\right)$ of CLZ and foreign species, i.e., dopamine, uric acid, caffeic acid, glucose, hydroquinone, catechol, carbofuran, ascorbic acid, urea, bisphenol, $\mathrm{Cl}^{-}, \mathrm{Br}^{-}, \mathrm{I}^{-}, \mathrm{CO}_{3}{ }^{2-}, \mathrm{PO}_{4}{ }^{3-}, \mathrm{NO}_{3}{ }^{-}, \mathrm{Cu}^{2+}, \mathrm{SO}_{4}{ }^{2-}, \mathrm{Ca}^{2+}, \mathrm{Mg}^{2+}$ and $\mathrm{Zn}^{2+}$ were studied, and the results were given as a plot in Figure 9. As shown in the bar chart, the electrochemical nanosensor delivered an excellent current response to CLZ; however, 
negligible replies were observed for all the foreign species. Thus, the foreign species study clearly revealed that $\alpha-\mathrm{Fe}_{2} \mathrm{O}_{3}-\mathrm{CdO} / \mathrm{SPE}$ electrochemical nanosensor has good anti-interference ability and can be used for the selective detection of CLZ in agricultural food samples.

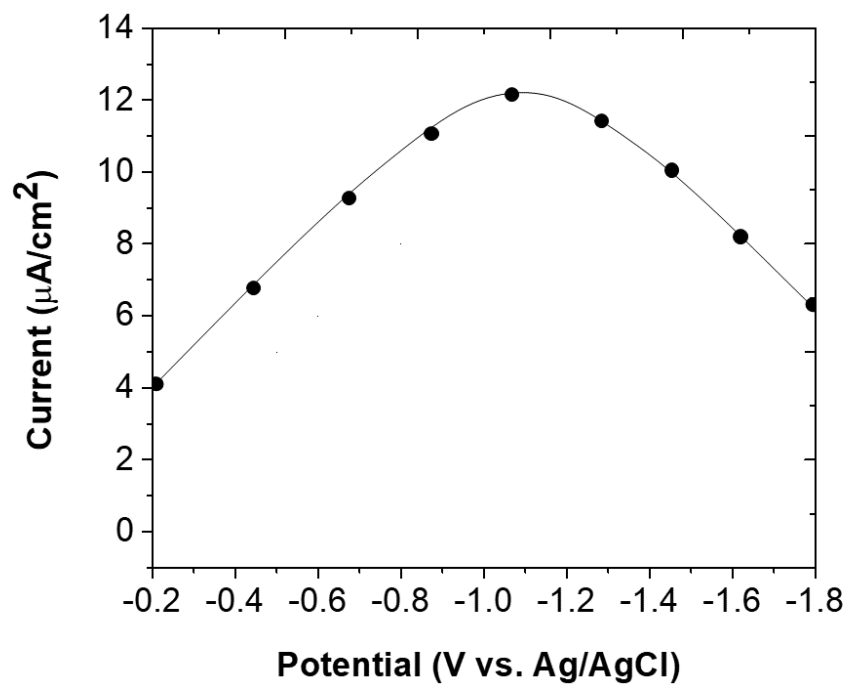

Figure 7. Effect of accumulation potential on the differential pulse voltammetric determination of CLZ at $\alpha$ -

$\mathrm{Fe}_{2} \mathrm{O}_{3}-\mathrm{CdO} / \mathrm{SPE}$; $\mathrm{pH}$ : 5.0 (BR buffer/acetonitrile); accumulation time: $40 \mathrm{~s}$; scan rate: $40 \mathrm{mVs}^{-1}$, pulse amplitude: $30 \mathrm{mV}$; concentration: $6.0 \mu \mathrm{g} \cdot \mathrm{mL}^{-1}$.

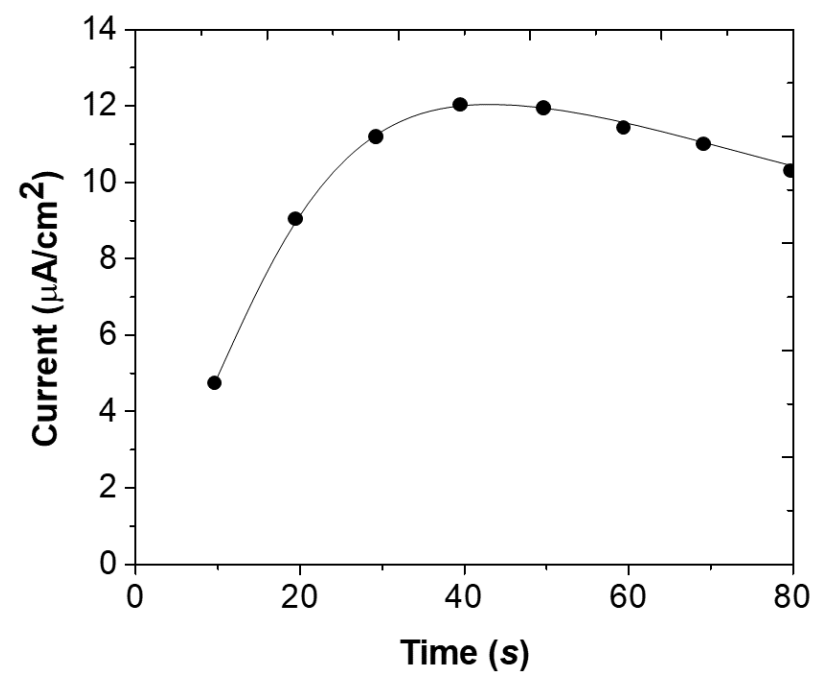

Figure 8. Effect of accumulation time on the differential pulse voltammetric determination of CLZ at $\alpha-\mathrm{Fe}_{2} \mathrm{O}_{3}$ CdO/SPE; pH: 5.0 (BR buffer/acetonitrile); accumulation potential: $-1.08 \mathrm{~V}$; scan rate: $40 \mathrm{mVs}^{-1}$, pulse amplitude: $30 \mathrm{mV}$; concentration: $6.0 \mu \mathrm{g} \cdot \mathrm{mL}^{-1}$.

The stability of the developed electrochemical nanosensor of $\alpha-\mathrm{Fe}_{2} \mathrm{O}_{3}-\mathrm{CdO}$ has been monitored when not used, and it was kept in the laboratory for 5 days. Through five days storage period, the electrode signals for a solution of CLZ $\left(6.0 \mu \mathrm{g} \cdot \mathrm{mL}^{-1}\right)$ were noted and compared with its response on the first day. According to the results, peak current had a small change (approx. 3\%), showing its significant stability. Subsequent reproducibility and repeatability of the developed electrochemical nanosensor, the DPV responses of $6.0 \mu \mathrm{g} \cdot \mathrm{mL}^{-1}$ of CLZ (Britton-Robison buffer/acetonitrile $(10: 1, \mathrm{~V} / \mathrm{V})$ ) for 5 successive times were evaluated. The developed electrochemical nanosensor exhibits appreciable repeatability with an RSD of $\sim 1.11 \%$ for five repetitive measurements. Further, the developed electrochemical nanosensor exhibits satisfactory reproducibility of $\alpha-\mathrm{Fe}_{2} \mathrm{O}_{3}-\mathrm{CdO}$ electrode. 


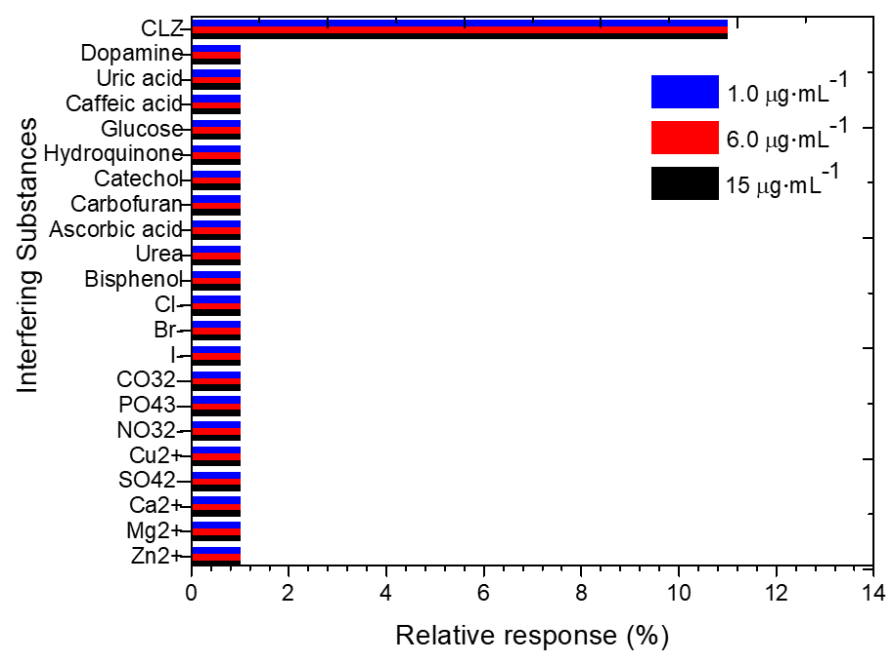

Figure 9. Bar chart of the selectivity to few foreign substances.

The stability of the developed electrochemical nanosensor of $\alpha-\mathrm{Fe}_{2} \mathrm{O}_{3}-\mathrm{CdO}$ has been monitored when not used, and it was kept in the laboratory for 5 days. Through five days storage period, the electrode signals for a solution of CLZ $\left(6.0 \mu \mathrm{g} \cdot \mathrm{mL}^{-1}\right)$ were noted and compared with its response on the first day. According to the results, peak current had a small change (approx. 3\%), showing its significant stability. Subsequent reproducibility and repeatability of the developed electrochemical nanosensor, the DPV responses of $6.0 \mu \mathrm{g} \cdot \mathrm{mL}^{-1}$ of CLZ (Britton-Robison buffer/acetonitrile (10:1, V/V)) for 5 successive times were evaluated. The developed electrochemical nanosensor exhibits appreciable repeatability with an RSD of $\sim 1.11 \%$ for five repetitive measurements. Further, the developed electrochemical nanosensor exhibits satisfactory reproducibility of $\alpha-\mathrm{Fe}_{2} \mathrm{O}_{3}-\mathrm{CdO}$ electrode.

\subsection{Applications.}

Under the optimized voltammetric conditions, the developed $\alpha-\mathrm{Fe}_{2} \mathrm{O}_{3}-\mathrm{CdO} / \mathrm{SPE}$ electrochemical nanosensor was applied for electrochemical detection of CLZ. Figure. 10 displayed the DPV of the $\alpha-\mathrm{Fe}_{2} \mathrm{O}_{3}-\mathrm{CdO} / \mathrm{SPE}$ in $0.1 \mathrm{M}$ pH 5.0 Britten-Robison buffer/acetonitrile supporting electrolyte at a potential range from $-0.2 \mathrm{~V}$ to $-1.6 \mathrm{~V}$ in the presence of various CLZ concentrations (0, 0.05, 2.0, 4.0, 8.0, 12.0, 16.0, 20.0, 24.0, 28.0 and $36.0 \mu \mathrm{g} \cdot \mathrm{mL}^{-1}$ ). As shown in the figure, the peak current density increased with the increase of CLZ concentration, suggesting that the presence of the CLZ can enhance the reaction on the modified electrode, which can be speculated that CLZ had a high binding affinity with CdO and $\alpha-\mathrm{Fe}_{2} \mathrm{O}_{3}$ hybrid nanocomposites.

To show the validation of the proposed method, the analytical features of the method, such as linear range of the calibration curve, detection limit, limit of quantification, accuracy, and precision was examined. Figure 11 shows the voltammograms of CLZ in the concentration range of $0.1-36.0 \mu \mathrm{g} \cdot \mathrm{mL}^{-1}$. Under the optimum conditions, the calibration graph for the determination of CLZ is obtained with a correlation coefficient of 0.995 . The regression equation for the line was $i_{p}=\mathrm{a} C(C L Z)+\mathrm{b}(\mathrm{n}=4)$, where $\mathrm{C}$ is the concentration of CLZ in $\mu \mathrm{g} \cdot \mathrm{mL}^{-1}$ and (i) is the peak current intensity difference (at the peak potential $-1.08 \mathrm{~V}$ ) between the analyte and the blank voltammograms. The slope of the line $b=0.6152 \pm 0.0137$ and the intercept of the line $\mathrm{a}=0.0906 \pm 0.238$ with a R.S.D $=1.01 \%$ were also obtained. 


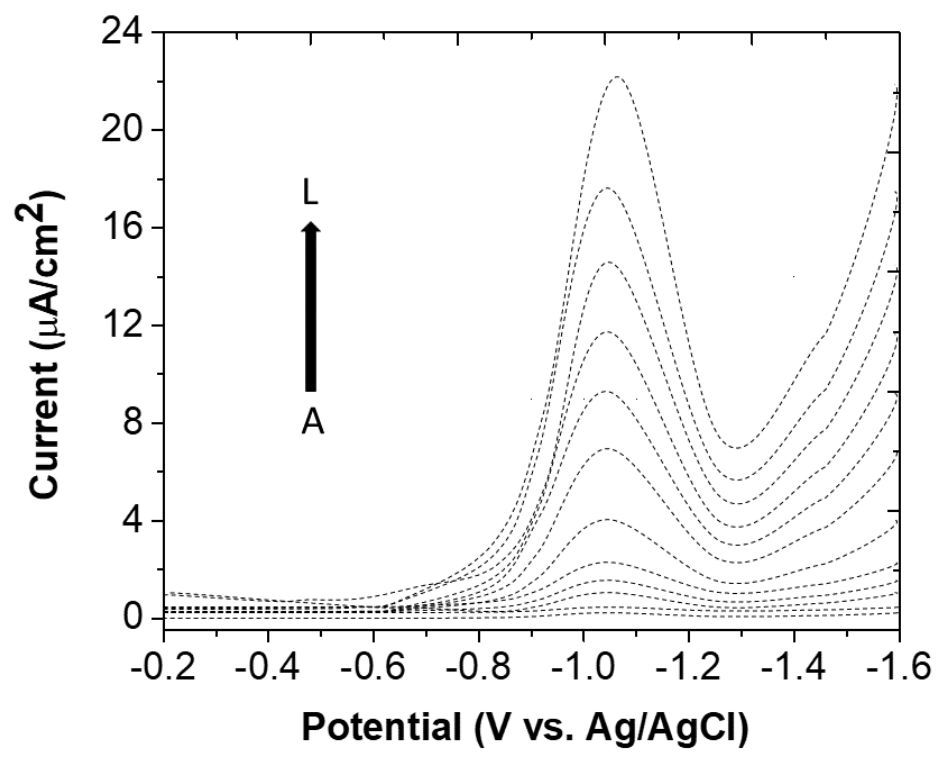

Figure 10. Differential pulse voltammograms of CLZ at $\alpha-\mathrm{Fe}_{2} \mathrm{O}_{3}-\mathrm{CdO} / \mathrm{SPE}$ obtained under optimized conditions, for CLZ concentration from (A) to (L): 0, 0.1, 0.5, 2.0, 4.0, 8.0, 12.0, 16.0, 20.0, 24.0, 28.0 and 36.0 $\mu \mathrm{g} \cdot \mathrm{mL}^{-1}$ at pH: 5.0 (BR buffer/acetonitrile); accumulation potential: $-1.08 \mathrm{~V}$; accumulation time: $40 \mathrm{~s}$; scan rate: $40 \mathrm{mVs}^{-1}$, pulse amplitude: $30 \mathrm{mV}$; concentration: $6.0 \mu \mathrm{g} \cdot \mathrm{mL}^{-1}$.

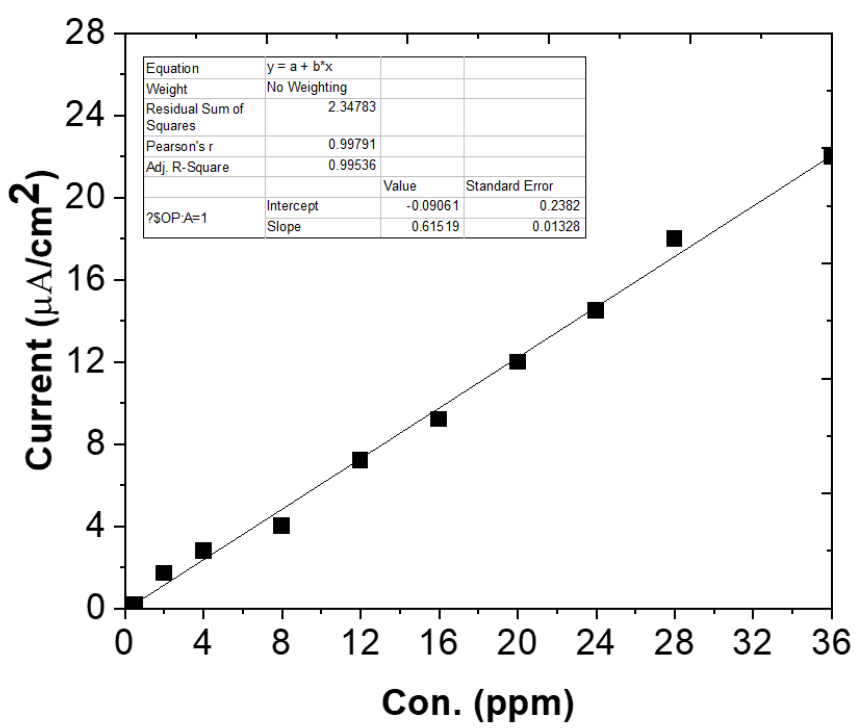

Figure 11. Linear curve for the CLZ determination by differential pulse voltammetry at $\alpha-\mathrm{Fe}_{2} \mathrm{O}_{3}-\mathrm{CdO} / \mathrm{SPE}$. $\mathrm{pH}$ : 5.0 (BR buffer/acetonitrile); accumulation potential: $-1.08 \mathrm{~V}$; accumulation time: $40 \mathrm{~s}$; scan rate: $40 \mathrm{mVs}^{-1}$, pulse amplitude: $30 \mathrm{mV}$.

The proposed $\alpha-\mathrm{Fe}_{2} \mathrm{O}_{3}-\mathrm{CdO}$ electrochemical nanosensor was further utilized to determine CLZ in agricultural food samples. The standard addition method was used to examine the reliability and accuracy of the proposed method; diverse volumes of CLZ standard additions were spiked into the agricultural food samples at the concentration of 5.0 and $25 \mu \mathrm{g}$ $\mathrm{mL}^{-1}$, respectively. The recoveries of CLZ in various (Spinach, Lettuce, Cauliflower, Cucumber, and Cabbage) spiked content of agricultural food samples were evaluated, and the results were presented in Table 1. Five replicate analyses of each sample were carried out to confirm the method's precision. In agricultural food samples, average recoveries ranged from 94.0-99.6\%, with an RSD of $\sim 1.0 \%$. Furthermore, the significant voltammetric characteristics of LOD and linear range were compared to modified electrodes previously reported. The proposed $\alpha-\mathrm{Fe}_{2} \mathrm{O}_{3}-\mathrm{CdO} / \mathrm{SPE}$ shows notable competitiveness to some previously reported electrodes (Table 2). 
Table 1. Application of the recommended method to determine CLZ in Agricultural food samples at $\alpha-\mathrm{Fe}_{2} \mathrm{O}_{3}$ CdO/SPE; pH: 5.0 (BR buffer/acetonitrile); accumulation potential: -1.08 V; accumulation time: 40 s; scan rate: $40 \mathrm{mVs}^{-1}$, pulse amplitude: $30 \mathrm{mV}$.

\begin{tabular}{l|l|l|l|l}
\hline \multirow{2}{*}{ Name of the sample } & $\begin{array}{l}\text { Amount added } \\
\left(\boldsymbol{\mu g} \cdot \mathbf{m L}^{-\mathbf{1}}\right)\end{array}$ & $\begin{array}{l}\text { Amount found } \\
\left(\boldsymbol{\mu g} \cdot \mathbf{m L}^{-\mathbf{1}}\right)\end{array}$ & $\begin{array}{l}\text { Recovery* } \\
(\boldsymbol{\%}) \pm \mathbf{S . D}\end{array}$ & $\mathbf{R S D ( \% )}$ \\
\hline \multirow{2}{*}{ Spinach leaves } & 5.0 & 04.8 & $96.0 \pm 0.083$ & 1.73 \\
\cline { 2 - 5 } & 25.0 & 24.9 & $99.6 \pm 0.210$ & 0.84 \\
\hline \multirow{2}{*}{ Lettuce } & 5.0 & 04.7 & $94.0 \pm 0.069$ & 1.47 \\
\cline { 2 - 5 } & 25.0 & 24.6 & $98.4 \pm 0.220$ & 0.90 \\
\hline \multirow{2}{*}{ Cauliflower } & 5.0 & 04.9 & $98.0 \pm 0.075$ & 1.53 \\
\cline { 2 - 5 } & 25.0 & 24.9 & $99.6 \pm 0.180$ & 0.72 \\
\hline \multirow{2}{*}{ Cabbage } & 5.0 & 04.8 & $98.0 \pm 0.011$ & 0.22 \\
\cline { 2 - 5 } & 25.0 & 24.6 & $98.4 \pm 0.064$ & 0.26 \\
\cline { 2 - 5 } & 5.0 & 04.9 & $98.0 \pm 0.090$ & 1.84 \\
\hline
\end{tabular}

$*_{\mathrm{n}=4}$ (no. of determinations); $\mathrm{S} . \mathrm{D}=$ Standard Deviation; $\mathrm{RSD}=$ Relative Standard Deviation

Table 2. Comparison of the biosynthesized $\alpha-\mathrm{Fe}_{2} \mathrm{O}_{3}-\mathrm{CdO} / \mathrm{SPE}$ electrochemical sensor with other reported electrodes for detection of pesticides.

\begin{tabular}{l|l|l|l|l}
\hline Modified electrodes & Technique/method & Linear range & LOD & Ref. \\
\hline $\mathrm{CoO} / \mathrm{rGO} / \mathrm{GCE}$ & DPV & $0.5-200 \mu \mathrm{M}$ & $0.037 \mu \mathrm{M}$ & {$[30]$} \\
\hline $\mathrm{CP}-\mathrm{SPE}$ & $\mathrm{DPV}$ & $0.1-1000 \mu \mathrm{M}$ & $0.08 \mu \mathrm{M}$ & {$[32]$} \\
\hline $\mathrm{ZXCPE}$ & DPV & $1.0-100 \mu \mathrm{M}$ & $0.3 \mu \mathrm{M}$ & {$[33]$} \\
\hline $\mathrm{MoS}_{2} \mathrm{NTs} / \mathrm{GCE}$ & $\mathrm{DPV}$ & $1.0-55 \mathrm{ng} \mu \mathrm{L}^{-1}$ & $0.32 \mathrm{ng} \mu \mathrm{L}^{-1}$ & {$[34]$} \\
\hline $\mathrm{AuNP} / \mathrm{DNA} / \mathrm{GE}$ & $\mathrm{DPV}$ & $1-100 \mu \mathrm{M}$ & $1.30 \mu \mathrm{M}$ & {$[35]$} \\
\hline $\mathrm{PGC}$ & $\mathrm{CV}$ & $5-500 \mathrm{mg} \mathrm{L}^{-1}$ & $8.7 \mathrm{mg} \mathrm{L}^{-1}$ & {$[36]$} \\
\hline $\mathrm{BiFE}$ & $\mathrm{DPV}$ & $9.5-200 \mu \mathrm{M}$ & $2.9 \mu \mathrm{M}$ & {$[37]$} \\
\hline $\mathrm{Hg}(\mathrm{Ag}) \mathrm{FE}$ & $\mathrm{SWV}$ & $3.55-185.6 \mu \mathrm{M}$ & $1.05 \mu \mathrm{M}$ & {$[38]$} \\
\hline Boran-doped diamond & SWV & $4.95-36.7 \mu \mathrm{M}$ & $4.1 \mu \mathrm{M}$ & {$[39]$} \\
\hline$\alpha-\mathrm{Fe}_{2} \mathrm{O}_{3}$-CdO/SPE & $\mathrm{DPV}$ & $0.1-36 \mu \mathrm{g} \cdot \mathrm{mL}^{-1}$ & $0.059 \mu \mathrm{g} \cdot \mathrm{mL}^{-1}$ & This Work \\
\hline
\end{tabular}

SWV: square wave voltammetry; CV: cyclic voltammetry; rGO: reduced graphene oxide; CP-SPE; carbon pastescreen printed electrode; GCE: glassy carbon electrode; BiFE: Bismuth-film electrode; $\mathrm{Hg}(\mathrm{Ag}) \mathrm{FE}$ : silveramalgam film electrode; ZxCPE: zeolite X modified carbon paste electrode, DNA: deoxyribonucleic acid.

\section{Conclusions}

The modest, good sensitive conventional $\alpha-\mathrm{Fe}_{2} \mathrm{O}_{3}-\mathrm{CdO} / \mathrm{SPE}$ electrochemical nanosensor was efficaciously applied for CLZ determination in agricultural food samples. The influence of scan rate, diverse concentration, and $\mathrm{pH}$ of the electrolytes was studied. Under the voltammetric optimized operating conditions, the $\alpha-\mathrm{Fe}_{2} \mathrm{O}_{3}-\mathrm{CdO} / \mathrm{SPE}$ electrochemical nanosensor showed a good linear range, low detection limit, and excellent electrical conductivity, which leads to a fast electron transfer rate. Moreover, the practical applicability of the biosynthesized nanosensor was demonstrated as it gave good (94.0\% to 99.6\%) recoveries of CLZ in agricultural food samples with an RSD of $\sim 1.11 \%$. The experimental results are conventional in that the proposed method has great potential for fast, modest, high sensitivity, selectivity, low cost, strong stability, and reproducibility for the detection of CLZ.

\section{Funding}

This research received no external funding.

\section{Acknowledgments}

We are grateful to Prof. N.Y. Sreedhar, Department of Chemistry, Sri Venkateswara University, Tirupati, for instrumentation support. 


\section{Conflicts of Interest}

The authors declare that there is no conflict of interest for this manuscript publication.

\section{References}

1. Yan, F.; Spyrou, K.; Thomou, E.; Kumar, S.; Cao, H.; Stuart, M.C.A.; Pei, Y.; Gournis, D.; Rudolf, P. Smectite clay pillared with copper complexed polyhedral oligosilsesquioxane for adsorption of chloridazon and its metabolites. Environmental Science: Nano 2020, 7, 424-436, https://doi.org/10.1039/C9EN00974D.

2. Yan, F.; Kumar, S.; Spyrou, K.; Syari’ati, A.; De Luca, O.; Thomou, E.; Alfonsín, E.M.; Gournis, D.; Rudolf, P. Highly Efficient Remediation of Chloridazon and Its Metabolites: The Case of Graphene Oxide Nanoplatelets. ACS ES\&T Water 2021, 1, 157-166, https://doi.org/10.1021/acsestwater.0c00037.

3. Flores-Céspedes, F.; Daza-Fernández, I.; Villafranca-Sánchez, M.; Fernández-Pérez, M.; Morillo, E.; Undabeytia, T. Lignin and ethylcellulose in controlled release formulations to reduce leaching of chloridazon and metribuzin in light-textured soils. Journal of Hazardous Materials 2018, 343, 227-234, https://doi.org/10.1016/j.jhazmat.2017.09.012.

4. Zhao, J.; Chi, Z.; Dong, H.; Sun, C.; Yu, H.; Yu, H. Degradation of desphenyl chloridazon in a novel synergetic electrocatalytic system with $\mathrm{Ni}-\mathrm{Sb}-\mathrm{SnO} 2 / \mathrm{Ti}$ anode and PEDOT/PSS-CNTs modified air diffusion cathode. Journal of Cleaner Production 2021, 300, https://doi.org/10.1016/j.jclepro.2021.126961.

5. El-Said, W.A.; El-Khouly, M.E.; Ali, M.H.; Rashad, R.T.; Elshehy, E.A.; Al-Bogami, A.S. Synthesis of mesoporous silica-polymer composite for the chloridazon pesticide removal from aqueous media. Journal of Environmental Chemical Engineering 2018, 6, 2214-2221, https://doi.org/10.1016/j.jece.2018.03.027.

6. Hegazy, A.M.; Abdelfatah, R.M.; Mahmoud, H.M.; Elsayed, M.A. Two spectrophotometric methods for quantitative determination of some pesticides applied for cucumber in Egypt. Beni-Suef University Journal of Basic and Applied Sciences 2018, 7, 598-605, https://doi.org/10.1016/j.bjbas.2018.07.002.

7. Kotal, F.; Kožíšek, F.; Jeligová, H.; Vavrouš, A.; Mayerová, L.; Gari, D.W.; Moulisová, A. Monitoring of pesticides in drinking water: finding the right balance between under- and over-monitoring - experience from the Czech Republic. Environmental Science: Processes \& Impacts 2021, 23, 311-322, https://doi.org/10.1039/D0EM00389A.

8. Danek, M.; Fang, X.; Tang, J.; Plonka, J.; Barchanska, H. Simultaneous determination of pesticides and their degradation products in potatoes by MSPD-LC-MS/MS. Journal of Food Composition and Analysis 2021, 24, https://doi.org/10.1016/j.jfca.2021.104129.

9. Tutarli, A.; Cici, M.; Çelik, S. Determination of Trifluralin and Chloridazon Residues in Agricultural Lands in Elazig Province. Environmental Technology 1995, 16, 995-1000, https://doi.org/10.1080/09593331608616337.

10. Yan, F.; Kumar, S.; Spyrou, K.; Syari'ati, A.; De Luca, O.; Thomou, E.; Alfonsín, E.M.; Gournis, D.; Rudolf, P. Highly Efficient Remediation of Chloridazon and Its Metabolites: The Case of Graphene Oxide Nanoplatelets. ACS ES\&T Water 2021, 1, 157-166, https://doi.org/10.1021/acsestwater.0c00037.

11. El-Saeid, M.H.; Hassanin, A.S.; Bazeyad, A.Y.; Al-Otaibi, M.T. Rapid analytical method for the determination of 220 pesticide with their isomers by GCMS-TIC. Saudi Journal of Biological Sciences 2021, 28, 4173-4182, https://doi.org/10.1016/j.sjbs.2021.05.024.

12. Picó, Y.; Rodr1; x; guez, R.; Mañes, J. Capillary electrophoresis for the determination of pesticide residues. TrAC Trends in Analytical Chemistry 2003, 22, 133-151, https://doi.org/10.1016/S0165-9936(03)00302-9.

13. Li, C.; Begum, A.; Xue, J. Analytical methods to analyze pesticides and herbicides. Water environment research : a research publication of the Water Environment Federation 2020, 92, 1770-1785, https://doi.org/10.1002/wer.1431.

14. Wang, Y.; Shen, L.; Gong, Z.; Pan, J.; Zheng, X.; Xue, J. Analytical methods to analyze pesticides and herbicides. Water environment research : a research publication of the Water Environment Federation 2019, 91, 1009-1024, https://doi.org/10.1002/wer.1167.

15. Badawy, M.E.I. Development and validation of HPLC methods for analysis of chlorantraniliprole insecticide in technical and commercial formulations. Journal of Environmental Science and Health, Part B 2018, 53, 411-422, https://doi.org/10.1080/03601234.2018.1438829.

16. Moutcine, A.; Chtaini, A. Electrochemical determination of trace mercury in water sample using EDTA-CPE modified electrode. Sensing and Bio-Sensing Research 2018, 17, 30-35, https://doi.org/10.1016/j.sbsr.2018.01.002.

17. Momčilović, M.Z.; Milićević, J.S.; Ranđelović, M.S. Recent Advances in Electrochemical Determination of Pesticides. Journal of Nanoscience and Nanotechnology 2021, 21, 5795-5811, https://doi.org/10.1166/jnn.2021.19541.

18. Fallah, M.; Rahimnejad, M.; Asghary, M.; Mashkour, M. An electrochemical sensor based on a carbon paste electrode for the determination of buserelin. Analytical Methods 2020, 12, 33-38, https://doi.org/10.1039/C9AY01760G. 
19. Sylwia, S.; Radovan, M.; Bogusław, B.; Karel, V. Recent Applications of Silver Amalgam Electrodes for Analysis of Pharmaceuticals and Vitamins. Current Medicinal Chemistry 2018, 25, 4138-4151, https://doi.org/10.2174/0929867324666170920143245.

20. Grabarczyk, M.; Adamczyk, M. Bismuth film electrode and chloranilic acid as a new alternative for simple, fast and sensitive Ge(iv) quantification by adsorptive stripping voltammetry. RSC Advances 2018, 8, 1521515221, https://doi.org/10.1039/C8RA01160E.

21. Hua, Q.T.; Ruecha, N.; Hiruta, Y.; Citterio, D. Disposable electrochemical biosensor based on surfacemodified screen-printed electrodes for organophosphorus pesticide analysis. Analytical Methods 2019, 11, 3439-3445, https://doi.org/10.1039/C9AY00852G.

22. Costa-Rama, E.; Fernández-Abedul, M.T. Paper-Based Screen-Printed Electrodes: A New Generation of Low-Cost Electroanalytical Platforms. Biosensors 2021, 11, https://doi.org/10.3390/bios11020051.

23. García-Miranda Ferrari, A.; Rowley-Neale, S.J.; Banks, C.E. Screen-printed electrodes: Transitioning the laboratory in-to-the field. Talanta Open 2021, 3, https://doi.org/10.1016/j.talo.2021.100032.

24. Subbaiah, G.B.; Ratnam, K.V.; Janardhan, S.; Shiprath, K.; Manjunatha, H.; Ramesha, M.; Prasad, N.V.K.; Ramesh, S.; Babu, T.A. Metal and Metal Oxide Based Advanced Ceramics for Electrochemical BiosensorsA Short Review. Frontiers in Materials 2021, 8, 190-199, https://doi.org/10.3389/fmats.2021.682025.

25. Sayyed, S.G.; Mahadik, M.A.; Shaikh, A.V.; Jang, J.S.; Pathan, H.M. Nano-Metal Oxide Based Supercapacitor via Electrochemical Deposition. ES Energy \& Environment 2019, 3, 25-44, https://doi.org/10.30919/esee8c211.

26. Mohamad Nor, N.; Abdul Razak, K.; Lockman, Z. Physical and Electrochemical Properties of Iron Oxide Nanoparticles-modified Electrode for Amperometric Glucose Detection. Electrochimica Acta 2017, 248, 160-168, https://doi.org/10.1016/j.electacta.2017.07.097.

27. Chavali, M.S.; Nikolova, M.P. Metal oxide nanoparticles and their applications in nanotechnology. $S N$ Applied Sciences 2019, 1, https://doi.org/10.1007/s42452-019-0592-3.

28. Chu, X.; Zhou, S.; Zhang, W.; Shui, H. Trimethylamine sensing properties of nano-LaFeO3 prepared using solid-state reaction in the presence of PEG400. Materials Science and Engineering: B 2009, 164, 65-69, https://doi.org/10.1016/j.mseb.2009.06.014.

29. Karunakaran, C.; Vijayabalan, A. Photocatalytic Activities of CdO-Fe2O3, CdO-CuFe2O4 and CdOZnFe2O4 Nanocomposites. Materials Science Forum 2013, 764, 206-218, https://doi.org/10.4028/www.scientific.net/MSF.764.206.

30. Wang, M.; Huang, J.; Wang, M.; Zhang, D.; Chen, J. Electrochemical nonenzymatic sensor based on CoO decorated reduced graphene oxide for the simultaneous determination of carbofuran and carbaryl in fruits and vegetables. Food Chemistry 2014, 151, 191-197, https://doi.org/10.1016/j.foodchem.2013.11.046.

31. Smyth, M.R.; Osteryoung, J.G. A pulse polarographic investigation of parathion and some other nitrocontaining pesticides. Analytica Chimica Acta 1978, 96, 335-344, https://doi.org/10.1016/S00032670(01)83670-9.

32. Della Pelle, F.; Angelini, C.; Sergi, M.; Del Carlo, M.; Pepe, A.; Compagnone, D. Nano carbon black-based screen printed sensor for carbofuran, isoprocarb, carbaryl and fenobucarb detection: application to grain samples. Talanta 2018, 186, 389-396, https://doi.org/10.1016/j.talanta.2018.04.082.

33. Salih, F.E.; Achiou, B.; Ouammou, M.; Bennazha, J.; Ouarzane, A.; Younssi, S.A.; El Rhazi, M. Electrochemical sensor based on low silica X zeolite modified carbon paste for carbaryl determination. Journal of Advanced Research 2017, 8, 669-676, https://doi.org/10.1016/j.jare.2017.08.002.

34. Sinha, A.; Huang, Y.; Zhao, H. Preparation of 3D assembly of mono layered molybdenum disulfide nanotubules for rapid screening of carbamate pesticide diethofencarb. Talanta 2019, 204, 455-464, https://doi.org/10.1016/j.talanta.2019.06.040.

35. Ribeiro, J.A.; Carreira, C.A.; Lee, H.J.; Silva, F.; Martins, A.; Pereira, C.M. Voltammetric determination of paraquat at DNA-gold nanoparticle composite electrodes. Electrochimica Acta 2010, 55, 7892-7896, https://doi.org/10.1016/j.electacta.2010.03.058.

36. Ben Brahim, M.; Ahmadi, M.; Ammar, H.; Samet, Y. Determination of ultra-trace amounts of neonicotinoid insecticide imidacloprid by cyclic and square wave voltammetric methods using pretreated glassy carbon electrode. Global Nest Journal 2018, 20, 628-636, https://doi.org/10.30955/gnj.002509.

37. Guzsvány, V.; Kádár, M.; Papp, Z.; Bjelica, L.; Gaál, F.; Tóth, K. Monitoring of Photocatalytic Degradation of Selected Neonicotinoid Insecticides by Cathodic Voltammetry with a Bismuth Film Electrode. Electroanalysis 2008, 20, 291-300, https://doi.org/10.1002/elan.200704057.

38. Guzsvány, V.; Petrović, J.; Krstić, J.; Papp, Z.; Putek, M.; Bjelica, L.; Bobrowski, A.; Abramović, B. Renewable silver-amalgam film electrode for voltammetric monitoring of solar photodegradation of imidacloprid in the presence of $\mathrm{Fe} / \mathrm{TiO} 2$ and $\mathrm{TiO} 2$ catalysts. Journal of Electroanalytical Chemistry 2013, 699, 33-39, https://doi.org/10.1016/j.jelechem.2013.04.003.

39. Lima, T.; Silva, H.T.D.; Labuto, G.; Simões, F.R.; Codognoto, L. An Experimental Design for Simultaneous Determination of Carbendazim and Fenamiphos by Electrochemical Method. Electroanalysis 2016, 28, 817822, https://doi.org/10.1002/elan.201500568. 